\title{
The Degradation of Lignin-related Compounds by Aspergillus flavus
}

\author{
By W. B. BETTS $\dagger$ AND R. K. DART* \\ Microbiology Section, Department of Chemistry, University of Technology, Loughborough, \\ Leicestershire, LE11 3TU, UK
}

(Received 25 January 1988; revised 13 May 1988)

Lignin-related compounds containing the $\beta$-aryl ether linkage were metabolized by Aspergillus flavus as sole carbon source. Growth measurements were made and degradation intermediates were identified using thin-layer chromatography, gas-liquid chromatography, and infra-red, proton nuclear magnetic resonance and mass spectroscopy. Degradation pathways were established by the detection of methanol as the product of demethoxylation reactions, and cleavage of the $\beta$-aryl ether bond was demonstrated by the use of a ${ }^{14} \mathrm{C}$-labelled model compound.

\section{INTRODUCTION}

Lignin is an amorphous high-molecular-mass polymer composed of phenylpropane subunits interconnected by a variety of non-hydrolysable bonds (Sarkanen \& Ludwig, 1971; Adler, 1977; Higuchi, 1982). Of the relatively few groups of micro-organisms that can degrade the macromolecule the most efficient degraders are the white-rot fungi, which can cleave $\mathrm{C} \alpha-\mathrm{C} \beta$, $\beta$-aryl ether, $\mathrm{Cl}-\mathrm{C} \alpha$ bonds and aromatic rings. They are also able to oxidize $\alpha$-carbons as well as hydroxylating aromatic rings and demethylating methoxy groups (Ander et al., 1985; Buswell et al., 1982; Eriksson et al., 1984; Kuwahara et al., 1984; Tien \& Kirk, 1984). Much of the research on white-rot fungi has centred upon the organism Phanerochaete chrysosporium. The brown-rot fungi can only cause limited degradation (Kirk, 1971; Ander \& Eriksson, 1978) and the soft-rot fungi usually cause only very slow and minor modifications to lignin (Ander \& Eriksson, 1978; Crawford, 1981).

Several other groups of fungi regarded as wood-rotting (Drew \& Kadam, 1979; Crawford \& Crawford, 1980; Kadam \& Drew, 1986), and bacteria (Crawford et al., 1983; McCarthy \& Broda, 1984), have been shown to degrade lignin.

To simplify the study of lignin degradation, model compounds are frequently used. These can be monomeric but are often dimeric aromatic compounds containing one or more of the most common linkages found in the macromolecule. The mechanisms underlying the metabolism of these models is then assumed to be applicable to the degradation of lignin. There is some dispute as to the validity of the use of model compounds but much of the present understanding of lignin biodegradation has arisen from their study.

In this paper we provide evidence for the degradation of lignin-related and other aromatic compounds containing the $\beta$-aryl ether linkage by Aspergillus flavus. This fungus is often found in wood-rotting environments and has been listed as a soft-rot organism (Seeman et al., 1975). It has previously been found to attack whole wood and lignin model compounds (Iyayi \& Dart, 1982; Betts et al., 1987a, b; Dart et al., 1987).

† Present address: Department of Biology, University of York, Heslington, York YO1 5DD, UK. 


\section{METHODS}

Maintenance and growth of organism. Aspergillus flavus IMI 15959 was obtained from CAB International, Ferry Lane, Kew, Surrey, UK. The organism was maintained on slopes of malt agar (pH 5.2) and was subcultured at intervals of 2 weeks.

The organism was induced to sporulate by growth at $30^{\circ} \mathrm{C}$ on a medium containing $\left(1^{-1}\right): \mathrm{K}_{3} \mathrm{PO}_{4} . \mathrm{H}_{2} \mathrm{O}, 2 \mathrm{~g}$; $\mathrm{KNO}_{3}, 2 \mathrm{~g} ; \mathrm{CaCl}_{2}, 0.25 \mathrm{~g}$; yeast extract, $5 \mathrm{~g}$; glucose, $10 \mathrm{~g}$; Bacto Casamino acids, $5 \mathrm{~g}$; metals solution, $0.1 \mathrm{ml}$. The metals solution consisted of $\left(\mathrm{ml}^{-1}\right): \mathrm{MgSO}_{4} .7 \mathrm{H}_{2} \mathrm{O}, 0.05 \mathrm{mg} ; \mathrm{ZnSO}_{4}, 0.002 \mathrm{mg} ; \mathrm{FeSO}_{4}, 0.002 \mathrm{mg} ; \mathrm{MnSO}_{4}$, $0.001 \mathrm{mg} ; \mathrm{CuSO}_{4}, 0.005 \mathrm{mg}$. The $\mathrm{pH}$ was adjusted to 5.2 before autoclaving.

The fungal growth medium comprised (1-1): $\mathrm{NaNO}_{3}, 5 \mathrm{~g} ; \mathrm{KH}_{2} \mathrm{PO}_{4}, 5 \mathrm{~g} ; \mathrm{MgSO}_{4} .7 \mathrm{H}_{2} \mathrm{O}, 0.5 \mathrm{~g}$; yeast extract, $0.1 \mathrm{~g}$; aromatic carbon source, $1 \mathrm{~g}$. The $\mathrm{pH}$ of the medium was adjusted to 5.2 before autoclaving. Flasks ( 1 litre) containing $500 \mathrm{ml}$ medium were inoculated with $1 \mathrm{ml}$ of a spore suspension containing $10^{5}$ spores $\mathrm{ml}^{-1}$ and incubated in a rotary shaker at $30^{\circ} \mathrm{C}$ and 120 r.p.m. Samples were taken for chemical analysis after $3 \mathrm{~d}$.

Synthesis of lignin model compounds. 1-(3,4-Dimethoxyphenyl)-2-(2-methoxyphenoxy)ethanol (compound 1), 3,4-dimethoxy- $\omega$-(2-methoxyphenoxy)acetophenone (compound 2$)$ and 4-hydroxy-3-methoxy-phenyl- $\omega$-(2-methoxyphenoxy)acetophenone (compound 3) were synthesized using modifications to the methods of Alder et al. (1952) and Landucci et al. (1981).

1-(3,4-Dimethoxyphenyl)-2-(2-phenylphenoxy)ethanol (compound 4), 3,4-dimethoxy- $\omega$-(2-phenylphenoxy)acetophenone (compound 5) and 4-hydroxy-3-methoxyphenyl- $\omega$-(2-phenylphenoxy)acetophenone (compound 6) were synthesized by the same methods but 2-phenylphenol replaced guaiacol.

3,4-Dimethoxy- $\omega$-(2-methoxyphenyl)acetophenone was synthesized with the C-2 carbon atom of the side-chain labelled with ${ }^{14} \mathrm{C}$ using modifications to the method of Landucci et al. (1981). Sodium $[1-14 \mathrm{C}]$ acetate solution $(250 \mu \mathrm{Ci}, 9 \cdot 25 \mathrm{MBq})$ was freeze-dried to remove the water prior to the addition of glacial acetic acid (1.5 ml). This was subsequently transferred to a three-necked flask fitted with a condenser, an inlet port for $\mathrm{BF}_{3}$ gas and a drying tube with an outlet connected to a series of traps containing water to absorb excess $\mathrm{BF}_{3}$. Guaiacol $\left(5 \cdot 80 \times 10^{-3} \mathrm{M}\right)$ was added and the solution was stirred magnetically in an ice bath and a very slow stream of $\mathrm{BF}_{3}$ gas was then introduced into the reaction vessel. The solution turned red after approximately $15 \mathrm{~min}$; after $2 \mathrm{~h}$ the $\mathrm{BF}_{3}$ supply was disconnected and a $10 \%(\mathrm{w} / \mathrm{v})$ solution of sodium acetate was poured into the flask. A yellow precipitate formed and the mixture was transferred into a separating funnel and extracted three times with $10 \mathrm{ml}$ portions of chloroform. The chloroform extract was washed with a saturated solution of $\mathrm{Na}_{2} \mathrm{CO}_{3}$ and water and was then evaporated under vacuum. The crude product was examined by TLC against an authentic sample of acetovanillone using a solvent system of benzene/ethyl acetate $(9: 1, \mathrm{v} / \mathrm{v})$ and was recrystallized from carbon tetrachloride to give pale yellow crystals of $\left[{ }^{14} \mathrm{C}\right]$ acetovanillone (yield $43 \%$ ).

$\left[{ }^{14} \mathrm{C}\right]$ Acetovanillone $\left(100 \mu \mathrm{Ci}, 3.7 \mathrm{MBq} ; 5.44 \times 10^{-3} \mathrm{M}\right)$, dimethyl sulphate $\left(2.44 \times 10^{-2} \mathrm{M}\right)$ and potassium carbonate $\left(1.11 \times 10^{-2} \mathrm{M}\right)$ in dry acetone $(30 \mathrm{ml})$ were refluxed for $5 \mathrm{~h}$. The reaction mixture was then cooled and filtered. Excess dimethyl sulphate and acetone were evaporated under a stream of nitrogen. The red/brown solid remaining was extracted with hot cyclohexane until TLC (solvent system was described above) showed that no product remained in the residue. The light brown product was then recrystallized from cyclohexane to leave $\left[{ }^{14} \mathrm{C}\right]$ acetoveratrone as a light brown powder (yield $55 \%$ ). This was used to synthesize ${ }^{14} \mathrm{C}$-labelled 3,4-dimethoxy$\omega$-(methoxyphenoxy)acetophenone in an identical way to the synthesis of the unlabelled compound (Adler et al., 1952).

All compounds were subjected to spectral analysis (IR, $\left.{ }^{13} \mathrm{C}-\mathrm{NMR},{ }^{1} \mathrm{H}-\mathrm{NMR}, \mathrm{MS}\right)$ to ensure their purity before use in degradation studies.

Isolation of intermediates. Mycelia were harvested from the medium by filtration and washed well with distilled water. The spent medium and washings were combined, adjusted to $\mathrm{pH} 2$ with $2 \mathrm{M}-\mathrm{H}_{2} \mathrm{SO}_{4}$ and then exhaustively extracted with ethyl acetate. The extracts were combined and dried over anhydrous $\mathrm{Na}_{2} \mathrm{SO}_{4}$. The drying agent was removed by filtration and the extract was evaporated to dryness on a rotary evaporator. The dark brown residue was dissolved in a small volume of acetone to give a $2 \%$ solution for application to TLC plates.

Analytical TLC plates (Whatman LK6 DF silica gel) were used to determine $R_{F}$ values. For preparative TLC, $1 \mathrm{~mm}$ thick Kieselgel $60 \mathrm{GF}_{254}$ on $20 \times 20 \mathrm{~cm}$ glass plates was used. The solvent systems were benzene/dioxane/acetic acid $(90: 25: 4$, by vol.) and benzene/ethyl acetate $(9: 1, \mathrm{v} / \mathrm{v})$. Visualization was by UV light. Bands were scraped from preparative plates and the silica gel was extracted five times with acetone. The extract was then filtered using a sintered disc funnel and reduced to a small volume on a rotary evaporator. A control without substrate and an uninoculated control was treated in an identical manner.

Methanol produced from compounds (2) and (5) was determined by GLC. The system used was a Phase-Sep chromatograph with a Spectra-Physica SP4290 integrator. An FID detector was fitted to the instrument and the glass column was packed with $10 \%$ PPG on Chromosorb W, 80-100 mesh. The oven temperature was $70{ }^{\circ} \mathrm{C}$ and the carrier gas was $\mathrm{N}_{2}$ (8 p.s.i.). Butanol was used as the internal standard.

Samples of the growth medium ( $1 \mathrm{ml}$ ) were taken at $24 \mathrm{~h}$ intervals during growth of $A$. flavus on compounds (2) and (5). These aqueous samples were used to inject directly into the column. Methanol was identified by 
comparison of the retention times of peaks from samples with the retention time of an aqueous methanol standard. A control lacking substrate and an uninoculated control were also examined.

The $R_{F}$ values of intermediates were determined and compared with those of authentic samples. Isolates and authentic samples were also co-chromatographed. IR spectra were obtained on a Perkin-Elmer SP200 spectrophotometer, ${ }^{1} \mathrm{H}$-NMR spectra were recorded using a Perkin-Elmer R32 spectrometer and mass spectra were obtained on a Kratos MS 50/DS-55 mass spectrometer. Spectra were always compared with those of authentic samples.

Identification of ${ }^{14} \mathrm{C}$-labelled intermediates. Triplicate $250 \mathrm{ml}$ flasks, each containing $1 \mu \mathrm{Ci}(37 \mathrm{kBq}){ }^{14} \mathrm{C}$-labelled compound (3) in $100 \mathrm{ml}$ of growth medium, were incubated with $A$. flavus for $3 \mathrm{~d}$ under similar conditions to those used with unlabelled compounds. A sealed system was prepared allowing flasks to be gassed with sterile air. The outlet was attached to a trap containing $20 \%(\mathrm{w} / \mathrm{v}) \mathrm{KOH}$ to capture any ${ }^{14} \mathrm{CO}_{2}$ emitted. The contents of flasks were filtered and extracted using the procedure described above. The concentrated extract was diluted with exactly $1 \mathrm{ml}$ of redistilled acetone to allow application to analytical TLC plates for quantitative radio-analysis. Measured volumes of the acetone solution were applied to TLC plates together with a range of unlabelled standards. The plates were developed and visualized as described above. Spots corresponding to standards were outlined, scraped from the plates and extracted with acetone. Scintillation fluid $(5 \mathrm{ml}$ of Cocktail $\mathrm{T})$ was added to the residue after evaporation of the acetone. The radioactivity was measured using a scintillation counter. Uninoculated and substrate controls were used as indicated above.

\section{RESULTS}

\section{Identification of intermediates}

Extracts from media in which A. flavus was grown on compound (1) showed six major bands on TLC. Preparative TLC and spectral analysis of the isolates showed that these corresponded to: 1-(3,4-dimethoxyphenyl)-2-(2-methoxyphenoxy)ethanol (compound 1, unused substrate); 3,4-dimethoxy- $\omega$-(2-methoxyphenoxy)acetophenone (compound 2); 4-hydroxy-3-methoxy- $\omega$-(2methoxyphenoxy)acetophenone (compound 3); guaiacol; vanillic acid; and protocatechuic acid. The sequence in which the compounds were formed was determined by a replacement experiment using metabolites of compound (1) as the sole carbon source. The results are shown in Table 1 and the proposed degradation sequence is shown in Fig. 1.

Extracts from media in which $A$. flavus was grown on compound (4) also showed six major bands on TLC. Preparative TLC and spectral analysis of the isolates showed that these corresponded to: 1-(3,4-dimethoxyphenyl)-2-(2-phenylphenoxy)ethanol (compound 4, unused substrate); 3,4-dimethoxy- $\omega$-(2-phenylphenoxy)acetophenone (compound 5); 4-hydroxy-3methoxy- $\omega$-(2-phenylphenoxy)acetophenone (compound 6); 2-phenylphenol; vanillic acid; and protocatechuic acid. The sequence in which the compounds were formed was determined by a replacement experiment using metabolites of compound (4) as the sole carbon source. The results are shown in Table 1. The proposed degradation sequence is shown in Figure 1.

Table 1. Replacement experiments to establish the sequence of degradation of compounds (1) and (4) by A. flavus

\begin{tabular}{|c|c|c|c|c|c|c|}
\hline \multirow[b]{2}{*}{ Substrate } & \multicolumn{6}{|c|}{ Compounds isolated } \\
\hline & Compound & $\begin{array}{c}\text { Compound } \\
2\end{array}$ & $\begin{array}{c}\text { Compound } \\
3\end{array}$ & Guaiacol & Vanillate & $\begin{array}{c}\text { Proto- } \\
\text { catechuate }\end{array}$ \\
\hline Compound 1 & + & + & + & + & + & + \\
\hline Compound 2 & - & + & + & + & + & + \\
\hline Compound 3 & - & - & + & + & + & + \\
\hline Substrate & $\underset{4}{\text { Compound }}$ & $\begin{array}{c}\text { Compound } \\
5\end{array}$ & Compound & $\begin{array}{l}\text { 2-Phenyl- } \\
\text { phenol }\end{array}$ & Vanillate & $\begin{array}{c}\text { Proto- } \\
\text { catechuate }\end{array}$ \\
\hline Compound 4 & + & + & + & + & + & + \\
\hline Compound 5 & - & + & + & + & + & + \\
\hline Compound 6 & - & - & + & + & + & + \\
\hline
\end{tabular}


<smiles>[R]c1ccccc1OCC(O)c1ccc(OC)c(OC)c1</smiles>

(4)<smiles>[R]c1ccccc1OCC(C)C</smiles>

2<smiles>[R]c1ccccc1OCC(C)C</smiles>

3<smiles>COc1cc(C(=O)O)ccc1O</smiles><smiles>[R]c1ccccc1OC</smiles><smiles>COOc1ccccc1</smiles>

(6)

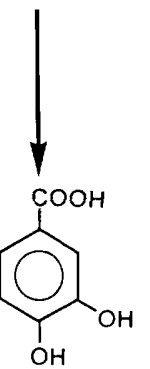

Fig. 1. Proposed sequence of degradation of compounds (1) and (4) by A. flavus.

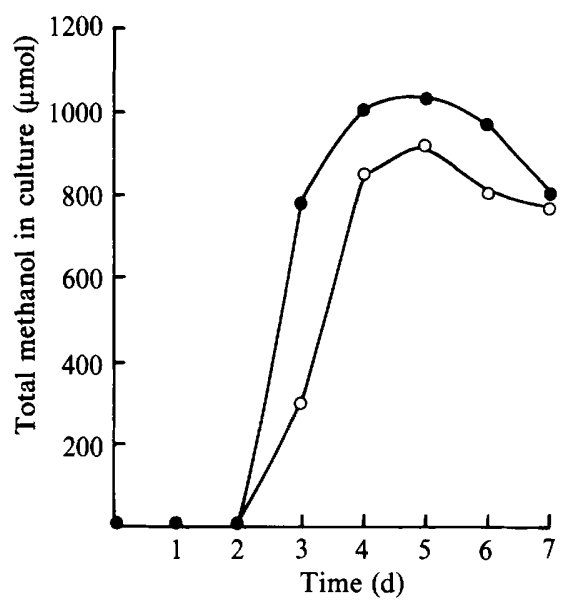

Fig. 2. Methanol production by A. flavus during growth on compounds (2) and (5). Samples of the growth medium containing either compound (2) (initial amount $332 \mu \mathrm{mol}$; $)$ ) or compound (5) (initial amount $387 \mu \mathrm{mol} ; O)$ as carbon source were taken at $24 \mathrm{~h}$ intervals and assayed for methanol by GLC as described in Methods.

When the aqueous medium which contained compound (2) as sole carbon source was assayed for methanol by GLC, a positive result was obtained. Its identity was confirmed by cochromatography with an authentic sample. Methanol production over a $7 \mathrm{~d}$ growth period is shown in Fig. 2. No methanol was deteeted in the controls. The maximum amount of methanol produced during metabolism of compounds (2) and (5) was almost equivalent to the theoretically calculated amounts from three and four methoxyl groups respectively (Fig. 2).

\section{Identification of ${ }^{14} \mathrm{C}$-labelled intermediates}

The first monomeric units produced during metabolism of compound (2) by A. flavus were shown to be vanillic acid and guaiacol (Table 1). When $\left[2-{ }^{14} \mathrm{C}\right]$ compound $(2)$ was used as substrate, $\left[2-{ }^{14} \mathrm{C}\right]$ compound (2) (unused substrate), $\left[2-{ }^{14} \mathrm{C}\right]$ compound $(3)$ and $\left[{ }^{14} \mathrm{C}\right]$ guaiacol were detected after degradation by $A$. flavus for $3 \mathrm{~d}$ (Table 2). No other radiolabelled intermediates were detected. 
Table 2. Radioactive compounds isolated after incubation of A. flavus with $\left[2-{ }^{14} \mathrm{C}\right]$ compound (2)

$R_{F}$ values were obtained on Whatman LK6 DF silica gel plates. Solvent system 1 was benzene/ethyl acetate $(9: 1, \mathrm{v} / \mathrm{v})$; solvent system 2 was benzene/dioxane/acetic acid $\left(90: 25: 4\right.$, by vol.). $R_{F}$ values of authentic compounds are shown in parentheses.

\begin{tabular}{lccc} 
Compound & \multicolumn{3}{c}{} \\
\cline { 2 - 4 } $\begin{array}{c}R_{F} \text { values } \\
\text { isolated }\end{array}$ & Solvent system 1 & Solvent system 2 & $\begin{array}{c}\text { Percentage of } \\
\text { original activity }\end{array}$ \\
Compound (2) & $0.18(0.18)$ & $0.75(0.74)$ & 63.76 \\
Compound (3) & $0.12(0.11)$ & $0.66(0.65)$ & 5.08 \\
Guaiacol & $0.50(0.48)$ & $0.75(0.76)$ & 3.86
\end{tabular}

\section{DISCUSSION}

The first step in the degradation of compounds (1) and (4) by A. flavus is the oxidation of the $\alpha$ hydroxyl group to a carbonyl group. This may be analogous to the process by which white-rot fungi attack lignin and model compounds as they tend to produce a modified lignin with increased amounts of $\mathrm{C} \alpha$-carbonyl groups compared to undecayed lignin (Kirk \& Chang, 1974). Examples of this type of reaction are also found in non-white-rot fungi and bacteria (Crawford $e t$ al., 1973; Higuchi, 1980; Pelmont et al., 1985). However, the enzyme systems involved in this oxidation may differ considerably with different organisms and include an $\mathrm{NAD}^{+}$-dependent dehydrogenase (Pelmont et al., 1985), a $\mathrm{H}_{2} \mathrm{O}_{2}$-dependent extracellular enzyme (Renganathan $e t$ al., 1986), and a phenol oxidase (Shimada, 1980). Several lignin-degrading Fusarium species have been reported to secrete an enzyme which catalyses the oxidation of the primary alcohol group in the $\alpha, \beta$-unsaturated side-chain of guaiacylglycerol- $\beta$-coniferyl ether to the corresponding aldehyde. The enzyme appeared to be an aromatic alcohol oxidase (Janshekar \& Fiechter, 1983). The oxidation state at the $\alpha$-carbon is thought to be important to the mechanisms by which the $\mathrm{C} \alpha-\mathrm{C} \beta$ bond between monomers is broken (Fenn \& Kirk, 1984).

The second degradation step for compounds (1) and (4) is the demethylation of the 4-position methoxyl group. Lignin does not contain 4-methoxyl groups but the use of model compounds which include these is common. The demethylation of other methoxyl groups in lignin is typical in many groups of micro-organisms which attack the lignin polymer.

Demethylation mechanisms have not received as much attention as those for cleavage of the $\beta$-aryl ether in lignin research but there are several mechanisms proposed in the literature. Dagley (1978) proposed a hydroxylation of the methyl ether to form a hemiacetal. This is thought to undergo spontaneous aldol cleavage to give formaldehyde and the corresponding phenol. Donnelly \& Dagley (1981) and Kersten et al. (1982) devised a mechanism in which the ether linkage was converted via a series of reactions to an ester which was hydrolysed to release methanol and give various intermediates of aromatic ring degradation. More recently, Kersten et al. (1985) have proposed a demethylation by the ligninase system involving a one-electron oxidation of the methoxybenzene by the oxidized enzyme and subsequent addition of water to the cation radical. This is followed by or simultaneous with methoxy elimination as methanol. Previous work on the demethylation of coniferyl alcohol by $A$. flavus detected methanol but not formaldehyde (Iyayi \& Dart, 1982).

Metabolism of compounds (3) and (6) involved cleavage of the dimer in each case to yield guaiacol and vanillic acid from compound (3) and 2-phenylphenol and vanillic acid from compound (6). These products could have resulted from cleavage of either the aryl ether bond or the $C \alpha-C \beta$ bond. Direct cleavage of the $C \alpha-C \beta$ bond could have produced veratrole and vanillic acid with subsequent demethylation of veratrole to guaiacol (Fig. 3). Although veratrole was not found, this could be explained by a very rapid demethylation to guaiacol. Conversely, cleavage of the aryl ether bond of compound (3) may have resulted in guaiacol and a $\mathrm{C} 6-\mathrm{C} 2$ compound which was rapidly converted to vanillic acid. A similar explanation may be appropriate for the products of the degradation of compound (6).

The detection of radiolabelled guaiacol as a degradation product of $\left[2-{ }^{14} \mathrm{C}\right]$ compound (2) 


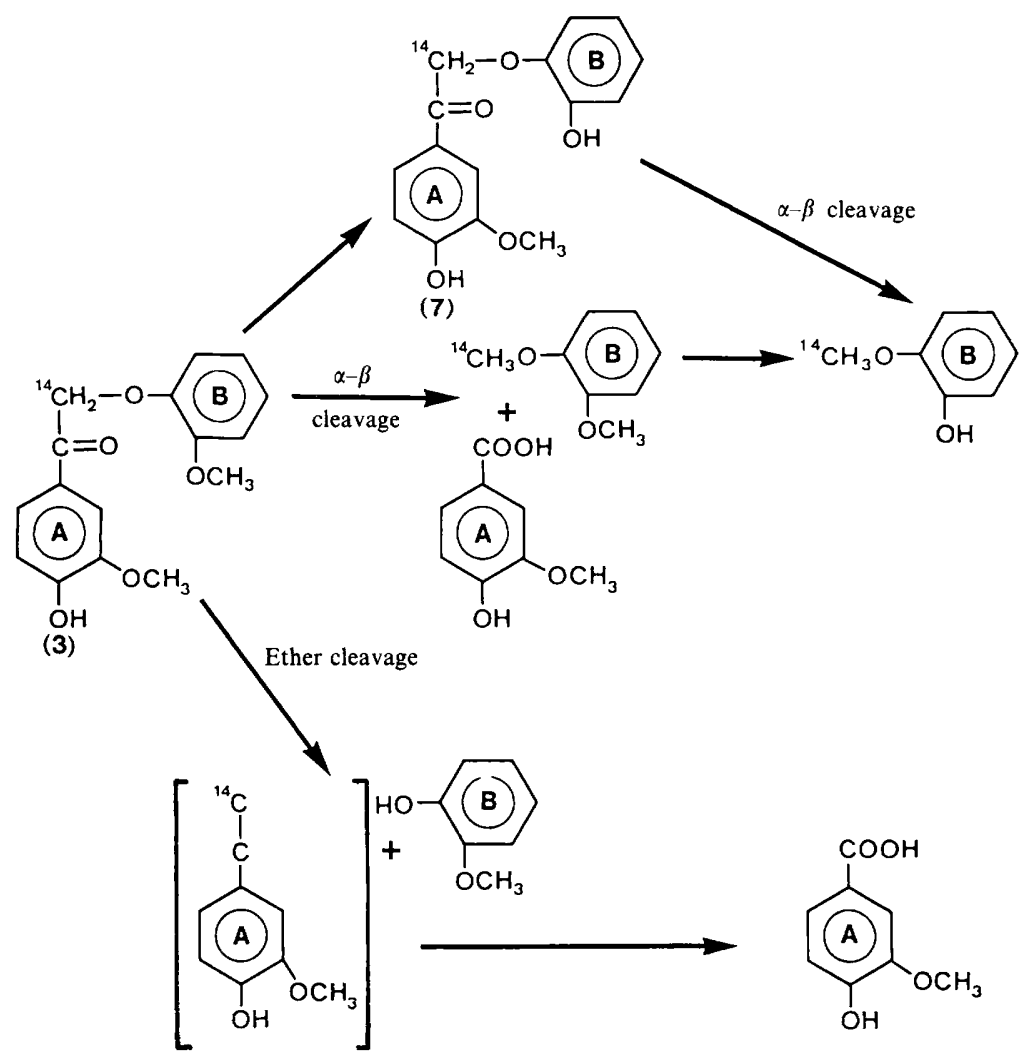

Fig. 3. Alternative hypothesis for cleavage of compound (3) by A. flavus.

indicated that the $\mathrm{C} \alpha-\mathrm{C} \beta$ bond had been cleaved and not the aryl ether bond, with a demethylation reaction occurring either before or after the cleavage. Demethylation before $\mathrm{C} \alpha-$ $\mathrm{C} \beta$ cleavage could have resulted in compound (7) (Fig. 3).

The quantity of methanol detected during growth of $A$. flavus on compound (2) also indicated that cleavage of the $\mathrm{C} \alpha-\mathrm{C} \beta$ bond occurred. The maximum amount of methanol detected (Fig. 2) was almost equivalent to the theoretically calculated amount derived from four methoxyl groups. Three of these are present in compound (2) itself. A further methoxyl group could have arisen from cleavage of the $C \alpha-C \beta$ bond. This could have appeared in veratrole if the $C \alpha-C \beta$ bond of compound (3) had been cleaved, or in guaiacol if compound (3) had been converted to compound (7) prior to $\mathrm{C} \alpha-\mathrm{C} \beta$ cleavage. Neither veratrole nor compound (7) was detected as an intermediate, but this may have been due to a rapid metabolism as explained above. The maximum amount of methanol produced during metabolism of compound (5) (Fig. 2) also almost equalled the theoretically calculated amount. This also supports a $\mathrm{C} \alpha-\mathrm{C} \beta$ cleavage of compound (5).

No further degradation products of guaiacol or 2-phenylphenol were detected, but protocatechuic acid was found, suggesting that vanillic acid had been demethylated. Conversion of vanillic acid to protocatechuic acid and its subsequent cleavage in $\boldsymbol{A}$. flavus has been previously established (Iyayi, 1981).

\section{REFERENCES}

ADLER, E. (1977). Lignin chemistry - past, present and future. Wood Science and Technology 11, 169-218. AdLER, E., LiNDGREN, B. O. \& SAEDEN, U. (1952). The $\beta$-guaiacyl ether of alpha-veratrylglycerol as a lignin model. Svensk papperstidning 15, 245-254.

ANDER, P. \& ERIKSSON, K. E. (1978). Lignin degrada- 
tion and utilization by micro-organisms. In Progress in Industrial Microbiology, vol. 14, pp. 1-58. Edited by M. T. Bull. Amsterdam: Elsevier.

ANDer, P., Eriksson, M. E. R. \& ERIKsson, K. E. (1985). Methanol production from lignin-related substances by Phanerochaete chrysosporium. Physiologia plantarum 65, 317-321.

BeTTS, W. B., BALL, M. C. \& DART, R. K. (1987a). Growth of Aspergillus flavus on an insoluble lignin model compound. Transactions of the British Mycological Society 89, 235-239.

BetTs, W. B., DarT, R. K. \& Ball, M. C. (1987b). Scanning electron microscope observations of fungal associations with lignin and insoluble dimeric lignin model compounds. Holzforschung 41, 337-341.

Buswell, J. A. ERIKsSON, K. E., GUPTA, J. K., Hamp, S. G. \& NORTH, I. (1982). Vanillic acid metabolism by selected soft-rot, brown-rot and white-rot fungi. Archives of Microbiology 131, 366-374.

Crawford, D. L. \& CRAWford, R. L. (1980). Microbial degradation of lignin. Enzyme and Microbial Technology 2, 11-22.

Crawford, D. L., McCoy, E., Harkin, J. M. \& JoNES, P. (1973). Production of microbial protein from waste cellulose by Thermomonospora fusca, a thermophilic actinomycete. Biotechnology and Bioengineering 15, 833-843.

Crawford, D. L., Pometto, A. L. \& Debald, L. A. (1983). The pathway of lignin degradation by Streptomyces: chemistry and enzymology. In Recent Advances in Lignin Degradation Research, pp. 78-95. Edited by T. Higuchi, H. M. Chang \& T. K. Kirk. Tokyo: Uni Publishers Company.

CRAWfORD, R. L. (1981). Lignin Biodegradation and Transformation, pp. 56-57. New York: Wiley Interscience.

DAGLeY, S. (1978). Pathways for the utilization of organic growth substances. In The Bacteria, vol. VI, pp. 305-388. Edited by L. N. Ornston \& J. R. Sokatch. New York: Academic Press.

DART, R. K., BetTs, W. B. \& BALL, M. C. (1987). Physical aspects of the degradation of insoluble triand tetrameric lignin model compounds by Aspergillus flavus. Microbios 49, 151-159.

Donnelly, M. I. \& DAGley, S. (1981). Bacterial degradation of 3,4,5-trimethoxycinnamic acid with production of methanol. Journal of Bacteriology 147, 471-476.

Drew, S. W. \& KaDAM, K. L. (1979). Lignin metabolism by Aspergillus fumigatus and white-rot fungi. Developments in Industrial Microbiology 20, 153-161.

Eriksson, K. E., Gupta, J. K., Nishida, A. \& Rao, M. (1984). Syringic acid metabolism by some white-rot, soft-rot and brown-rot fungi. Journal of General Microbiology 130, 2457-2464.

FENN, P. \& KIRK, T. K. (1984). Effect of C $\alpha$-oxidation in the fungal metabolism of lignin. Journal of Wood Chemistry and Technology 4, 131-148.

HiguCHI, T. (1980). Lignin structure and morphological distribution in plant cells walls. In Lignin Biodegradation: Microbiology, Chemistry and Potential Applications, vol. 1, pp. 1-19. Edited by T. K. Kirk, T. Higuchi \& H.-M. Chang. Boca Raton, Florida: CRC Press.

HiguchI, T. (1982). Biosynthesis of lignin. In Encyclopedia of Plant Physiology, New Series, vol. 136, Plant
Carbohydrates, Extracellular Carbonhydrates, pp. 194-220. Edited by F. A. Loewus \& N. Tanner. Berlin: Springer.

IYAYI, C. B. (1981). Degradation of lignin-related monomers. PhD thesis, University of Loughborough.

IYAYI, C. B. \& DART, R. K. (1982). The degradation of p-coumaryl alcohol by Aspergillus flavus. Journal of General Microbiology 128, 1473-1482.

JANSHEKAR, H. \& FIECHTER, A. (1983). Lignin: biosynthesis, application and biodegradation. In Advances in Biochemical Engineering/Biotechnology, vol. 27, pp. 119-179. Edited by A. Fiechter. Berlin: Springer.

KADAM, K. C. \& DREW, S. W. (1986). Study of lignin biotransformation by Aspergillus fumigatus and white-rot fungi using ${ }^{14} \mathrm{C}$-labelled and unlabelled Kraft lignins. Biotechnology and Bioengineering 28, 394-404.

Kersten, P. J., Dagley, S., Whittaker, J. W., ARCIERO, D. M. \& LIPSCOMB, J. D. (1982). 2-Pyrone4,6-dicarboxylic acid, a catabolite of gallic acids in Pseudomonas species. Journal of Bacteriology 152, 1154-1162.

Kersten, P. J., Ming Tien, Kalyanaraman, B. \& KIRK, T. K. (1985). The ligninase of Phanerochaete chrysosporium generates cation radicals from methoxybenzenes. Journal of Biological Chemistry 260, 2609-2612.

KIRK, T. K. (1971). Effects of micro-organisms on lignin. Annual Review of Phytopathology 9, 185-210.

KIRK, T. K. \& ChaNG, H.-M. (1974). Decomposition of lignin by white-rot fungi. I. Isolation of heavily degraded lignins from decayed spruce. Holzforschung 28, 217-222.

Kuwahara, M., Glenn, J. K., Morgan, M. A. \& GoLD, M. A. (1984). Separation and characterization of two extracellular $\mathrm{H}_{2} \mathrm{O}_{2}$-dependent oxidases from ligninolytic cultures of Phanerochaete chrysosporium. Archives of Microbiology 117, 277-285.

LANDUCCI, L. L., GeDdeS, S. A. \& KIRK, T. K. (1981). Synthesis of ${ }^{14} \mathrm{C}$-labelled 3-methoxy-4-hydroxy- $\alpha$-(2methoxyphenoxy)- $\beta$-hydroxypropiophenone, a lignin model compound. Holzforschung 35, 66-69.

MCCARTHY, A. J. \& BRODA, P. (1984). Screening for lignin degrading actinomycetes and characterization of their activity against $\left[{ }^{14} \mathrm{C}\right]$ lignin-labelled wheat lignocellulose. Journal of General Microbiology 130, 2905-2913.

Pelmont, J., Barrelle, M., Hauteville, M., Gamba, D., Romdhane, M., Dardas, A. \& Beguin, C. (1985). A new bacterial dehydrogenase oxidizing the lignin model compound guaiacylglycerol $\beta-\mathrm{O}-4$ guaiacyl ether. Biochimie 67, 973-986.

Renganathan, V., Miki, K. \& Gold, M. (1986). Role of molecular oxygen in lignin peroxidase reactions. Archives of Biochemistry and Biophysics 246, 155-161.

SARKANEN, K. V. (1971). In Lignins: Occurrence, Formation, Structure and Reactions. Edited by K. V. Sarkanen \& C. H. Ludwig, pp. 95-195. New York: Wiley Interscience.

SeEman, G., Leise, W. \& Kess, B. (1975). Lists of Fungi in Soft-rot Tests. International Research Group, Wood Preservation, Princes Risborough, UK, Document no. 1RG/WP/105.

SHIMADA, M. (1980). Stereobiochemical approach to lignin biodegradation: possible significance of non- 
stereospecific oxidation catalysed by laccase for lignin decomposition by white-rot fungi. In Lignin Biodegradation: Microbiology, Chemistry and Potential Applications, vol. 1, pp. 103-125. Edited by T. K. Kirk, T. Higuchi, \& H.-M. Chang. Florida: CRC Press.
TIEN, M. \& KIRK, T. K. (1984). Lignin-degrading enzyme from Phanerochaete chrysosporium: purification, characterization and catalytic properties of a unique $\mathrm{H}_{2} \mathrm{O}_{2}$-requiring oxygenase. Proceedings of the National Academy of Sciences of the United States of America 81, 2280-2284. 